\title{
3. Other non-political considerations and factors
}

\section{INTRODUCTION}

The previous chapter primarily focused on the application of the legal framework of Article 267 TFEU and the CILFIT exceptions. It discussed legal-formalist considerations that point to a strict adherence of this framework and a looser, more pragmatic approach. The following two chapters focus on other considerations and factors that go beyond the judges' application of the law. Chapter 4 focuses on politico-strategic motives; whereas this chapter focuses on several non-political factors. First, it considers personal and psychological factors and the individual background of judges (section 2). These include views on the judge's judicial role; the judge's knowledge of EU law and/or the preliminary reference procedure; and personal motives, reputational concerns and career implications. Second, institutional and organizational factors are discussed, including capacity and case management issues. Third, the role of parties and their requests to refer are examined.

\section{PERSONAL AND PSYCHOLOGICAL FACTORS}

The focus in this section fits into a recent trend in socio-legal scholarship which focuses on the agency of judges. ${ }^{1}$ As will be made clear, other empirical studies on national court references to the ECJ have also found that such factors play a major role.

\section{$2.1 \quad$ Judicial Role: Law versus Fact-Finders}

One of the most decisive factors behind the willingness of lower courts to refer is the judge's perspective on the court's judicial role as a court of first or second instance vis-à-vis the highest court(s), and more broadly, on the judge's role in the political system. Recent empirical studies of lower courts in Italy,

1 Posner 2008; Epstein et al 2013; Chehtman 2020; Rado 2020; Lampach and Dyevre 2019. 
Denmark, Slovenia and Croatia also emphasized this point as an important explanation for the reluctance of lower courts to refer. ${ }^{2}$ These studies also noted that some of the highest courts, and in some cases even the executive, have discouraged references from lower courts. ${ }^{3}$ There are notable differences between the Irish and Dutch courts in this respect, with UK courts sitting somewhere in between. One word of caution relates to the comparability of the three-layered Dutch legal system with the multi-layered court systems in the UK and Ireland, which have a wide variety of courts and tribunals, as discussed in Chapter 1. The Court of Appeal and High Court in the UK and Ireland are superior or intermediate appellate courts, and are therefore difficult to compare with the Dutch 'lower' courts (gerechtshoven and rechtbanken).

Several Dutch judges clearly indicated that references should primarily be made by the highest court(s), given the lower courts' more limited judicial law-making function and limited expertise and time. They generally consider referring to be the task of the highest court(s), even in case of doubt. ${ }^{4}$ This reluctance also stems from a widely shared satisfaction with and trust in the Dutch highest courts, given their willingness to refer. One judge, for example, stated that the Supreme Court is a 'fantastic' court with respect to EU law, with excellent and well-trained judges. ${ }^{5}$ According to most lower court judges, the role of the courts of first (and second) instance is to take decisions and resolve disputes. ${ }^{6}$ One department of tax law within a court of appeal had an unofficial policy of not referring, even where a matter was not clair or éclairé. ${ }^{7}$ The preference of the highest courts to refer is also laid down in a memo issued by the Committee of the Presidents of the Administrative Law Departments of District Courts and an instruction of a similar committee in the area of tax law. ${ }^{8}$ These signals even led one court to abstain from referring even though the questions had already been finalized in draft. ${ }^{9}$ The Dutch courts of appeal are slightly more inclined to refer, because there is more attention on law making

2 Glavina 2019, 2020a and b; Pavone 2018; Rameu 2002, 12-13; Stone Sweet and Brunell 1998, 73; Mayoral and Pérez 2018, 725.

3 Leijon and Glavina 2020. Cf Wind et al, 76 and 78.

4 Eg NL:GHARL:2014:2583, paras 4.8 and 10; Interviews 14, 29, 51, 55, 62, 58 and 74 .

5 Van Alphen 2017, 17 and 31.

6 Interview 74. Eg NL:GHARL:2014:35, para 4.8; NL:RBNNE:2013:BZ6427, para 3.15 .

7 Interview 51.

8 On file with the author: 'Werkwijze stellen van prejudiciële vragen', 12 June 2013; 'Aanbeveling: Stellen van prejudiciële vragen aan het Hof van Justitie van de Europese Unie binnen het bestuursrecht', undated; 'LOVBeL: Werkwijze stellen van prejudiciële vragen', 16 March 2015. Cf Storey et al 2014, 18-19.

9 Interview 25. 
and unity at this level, and because the facts are usually more crystallized at second instance (see also Chapter 2, section 3.1). ${ }^{10}$ Most Dutch lower civil and tax judges prefer to use the national preliminary ruling procedure introduced in private law in 2012 and in tax law in 2016. They choose to refer questions on the interpretation of EU law to the Supreme Court instead of referring directly to the ECJ themselves. One example is the questions submitted by the Zeeland-West Brabant District Court to the Supreme Court about whether a Latvian seafarer was obliged to pay social income tax and social security contributions in his state of residence. ${ }^{11}$ The district court noted in its reference that it preferred to submit questions to the Supreme Court so that the highest court could enter into a 'dialogue' with the ECJ, taking into account the importance of informing the ECJ as optimally as possible. ${ }^{12} \mathrm{~A}$ tax judge involved in this case also acknowledged that the reason for referring to the Supreme Court instead of the ECJ was mainly related to the idea that the Supreme Court would be better positioned to formulate good questions. ${ }^{13}$ Aside from the greater amounts of experience, time and expertise available at the Supreme Court, two other lower court judges also noted that a reference from the Supreme Court has more authority and is taken more seriously by the ECJ than a lower court reference. ${ }^{14}$ This example illustrates that the introduction of this national procedure reinforced the reluctance to refer to the ECJ. A similar phenomenon has been reported in other EU Member States, such as Spain. ${ }^{15}$

There are some exceptions to this general picture. Dutch judges with a specialized background in IP law, a few immigration law judges and judges of the Chamber for International Cooperation of the Amsterdam District Court are somewhat more eager to refer and do not feel restricted by this logic, often because of the highly specialized nature of the cases that they deal with. As will be discussed in section 2, this specialization has sometimes led to a culture that is more favourable to referral. The District Court of The Hague, for example, referred three IP cases in the studied period of 2013-16. ${ }^{16}$ One of these was Vereniging Openbare Bibliotheken, which concerned the lending of e-books by public libraries. ${ }^{17}$ The district court was eager to refer at first instance because it noted that a reference is the quickest way to obtain a definitive

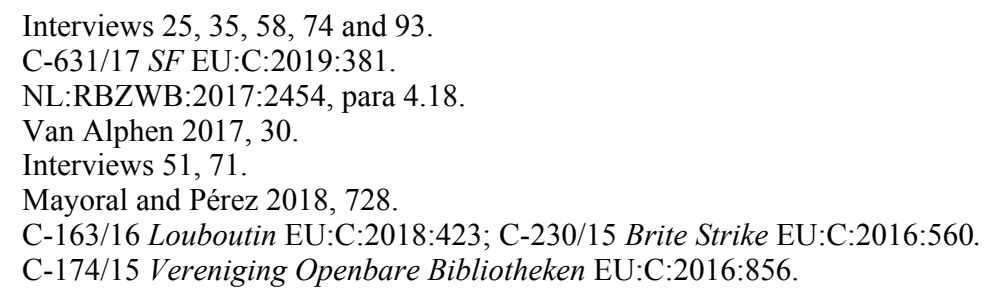


judicial opinion. ${ }^{18}$ Some of the specialized judges have also been activists and have referred on the basis of politico-strategic calculations, as discussed in the following chapter.

By contrast, most Irish judges apply a 'better sooner than later' logic. Decisions of the Irish Court of Appeal and the High Court in particular mention the advantages of early referral. Very few judgments were found in which the Dutch logic of leaving references to the highest courts was mentioned. ${ }^{19}$ Almost all High Court and Court of Appeal judges disagreed with the view that references should be left to the Supreme Court. There is a general idea that, if it is certain that a question must be referred at some point, it is beneficial that the first-instance court refers at an early stage. ${ }^{20}$ Waiting for the higher courts to refer could mean that some questions of EU law are ultimately not submitted to the ECJ and are thus 'left in vain'. ${ }^{21}$ This is even more so the case because, as some High Court judges noted, it can take up to two years to get a hearing at the Court of Appeal. High Court judges felt that they have more time to hear cases: 'I save them work when I refer myself when it is inevitable.' ${ }^{2}$ It would seem unacceptable to most High Court judges to decide an unclear point of EU law themselves - possibly incorrectly - because they preferred the superior courts to refer. Judges argued along the lines of, 'It is not for me to guess what the ECJ would say', or 'Who am I to cook up the law?' ${ }^{23}$ Likewise, one judge noted, 'I simply do not have the competence to make the decision', and hence decided to refer. ${ }^{24}$ Meanwhile, Irish High Court Judge Cooke decided to refer because he found it to be in the interests of the parties to resolve the points of law in question before the initiation of a Supreme Court appeal. ${ }^{25}$ High Court Judge Barrett also decided to refer the environmental case People over Winds and pointed to the risk of hoping that an appellate court would subsequently refer, while also mentioning the financial burden of an appeal. ${ }^{26}$ High Court

18 VOB NL:RBDHA:2014:10962, para 4.11.

19 One exception is Lofinmakin \& Ors v MJELR \& Ors [2011] IEHC 116 (Cooke J), para 6; Digital Rights Ireland Ltd v Minister for Communications, Marine and Natural Recources \& Ors [2017] IEHC 307 (Costello J), para 32.

20 Interviews 148, 155 and 181. Cf Minister for Justice and Equality $v$ Dunne No 3 [2018] IEHC 283 (Donnelly J), para 17.

21 Interview 148.

22 Ibid; Fahey 2007, 20.

23 Interviews 121, 133 and 181.

24 Interview 161. Cf Interviews 108, 136, 139, 159, 166, 181 and 187.

25 HID (A minor) \& Anor c Refugee Applications Comr [2013] IEHC 146 (Cooke J), para 31 (Case C-175/11 D en $A$ EU:C:2013:45).

26 People over Winds \& Anor c Coillte Teoranta [2017] IEHC 171 (Barrett J), para 21 (C-323/17). Cf Aer Lingus v Minister for Finance \& Ors [2018] IEHC 198 (Barrett J), para 46 . 
Judge Humphreys highlighted another advantage for the appellate court where a reference was made by the High Court in $M A$ about the transfer of a protection applicant under the Dublin III Regulation to the UK: one reason to refer at an early stage is to ensure that 'the reply from Luxembourg [is] digested and applied' before the case reaches the Court of Appeal or Supreme Court. ${ }^{27}$

The practice of the UK lower courts is more diverse. On the one hand, the relatively high number of 'lower' court references in the UK mirrors the Irish situation. Intermediate appellate courts have referred quite a lot because of their focus on law-finding and law creation. ${ }^{28}$ Like the Irish courts, the UK courts (and tribunals) have frequently acted in line with the 'better sooner than later' approach, emphasizing the benefits of early referral where it is likely that the case will need to be referred in any case and where all relevant facts have been found. ${ }^{29}$ The UK First Tier Tribunal, for example, held that a reference is cheaper, because 'onward appeals within the UK are likely to exceed the cost of a ECJ hearing' ${ }^{30}$ The UK High Court held in a family law case that 'the swiftest route to secure' authoritative determination is via Luxembourg. ${ }^{31}$ The UK Supreme Court recently pointed to the advantage of 'discretionary references' of lower courts 'in circumstances where it is likely that the Supreme Court would be bound to make a reference in any event. In this way, a discretionary reference can save time and expense'. ${ }^{32}$ On the other hand, however, numerous judgments reflect the Dutch logic of leaving a reference to the higher courts, even after concluding that the matter was not clair. ${ }^{33}$ One UK barrister noted that the lower courts tend to avoid 'rocking the boat' and thus leave referring to the final court. ${ }^{34}$ This is even more so the case

27 MA v The International Protection Appeals Tribunal \& Ors [2017] IEHC 677 (Humphreys J), para 140 (Case C-661/17 M.A. EU:C:2019:53).

28 Ovádek et al 2020, 142.

29 Eg Bookit Ltd v HMRC [2014] UKFTT 856 (TC), para 115; Sky plc \& Ors v Skykick UK Ltd \& Anor [2018] EWHC 155 (Ch), para 357; MG v Portugal [2012] UKUT 268 (IAC), para 34; HMRC v HD [2018] UKUT 148 (AAC), para 40; RP v SSWP [2016] UKUT 422 (AAC), para 77; O'Brien v Ministry of Justice [2015] EWCA Civ 1000.

30 Healthspan Ltd $v$ HMRC [2018] UKFTT 241 (TC), para 267.

$31 \quad M S v P S$ [2016] EWHC 88 (Fam), para 6.

32 Written response 15 April 2020. Cf Interview 208.

33 Eg Walton International Ltd \& Anor v Verweij Fashion BV [2018] EWHC 1608 (Ch), para 27; Safeway Ltd v Newton \& Anor [2016] EWHC 377 (Ch); Buckinghamshire County Council \& Ors, $R$ (on the application of) $v$ The Secretary of State for Transport [2013] EWHC 481 (Admin); The Trustees of the BT Pension Scheme HMRC FTC/91 and 92/2011 [2013] UKUT 105 (TCC), para 423 (later referred in Case C-628/15 The Trustees of the BT Pension Scheme EU:C:2017:687).

34 Interview 211. Cf Interviews 208 and 264; Kochenov and Lindeboom as discussed in Pollack 2017, 586. 
where the highest court has previously decided an issue without a reference. The lower courts are subsequently reluctant to second-guess such a decision out of respect for the judicial hierarchy (see further Chapter 4, section 4).

\subsection{Knowledge and Specialization}

A prerequisite for a reference is a certain level of knowledge about the procedure and EU law. Until 1990, most national court judges lacked the necessary knowledge to understand and apply EU law. ${ }^{35}$ Duke is an example of a case in 1988 in which even the highest UK court, the House of Lords, made considerable errors from the perspective of EU law. ${ }^{36}$ Today, knowledge seems to be less of a problem for the highest courts, especially in the older EU Member States. ${ }^{37}$ This book confirms the importance of knowledge and attributes the increase of references in Ireland in recent years partly to a generational change within the courts. The findings show that training and legal education have an important impact. ${ }^{38}$ Nonetheless, too much knowledge can discourage references, as was argued previously in relation to overconfident UK Supreme Court judges (see Chapter 2, section 3.2).

Limited knowledge may be a factor that hinders courts from referring. This is especially true of lower courts, which are sometimes 'nervous' to refer because they are not always well informed about the intricacies of EU law. ${ }^{39}$ An empirical study of primarily civil law lower courts in Germany, the Netherlands, Poland and Spain also found that judges are sceptical about their own knowledge. ${ }^{40}$ Surveys among national court judges found that the large majority of lower court judges lacked knowledge of how to make a reference. ${ }^{41}$ The interviews revealed that lower court judges did not mind acknowledging deficiencies in their knowledge. ${ }^{42}$ One Dutch civil law judge, for instance, stated that he/she was aware only of the key aspects of the procedure and that it was meant for the interpretation of EU law; otherwise, he/she knew very little. ${ }^{43}$ One judge referred to the fear of the unknown. ${ }^{44}$ Another Dutch tax law judge who had made several references noted that the reluctance of other tax

\footnotetext{
Rasmussen and Martinsen 2019, 264-65.

Duke v GEC Reliance Systems Ltd [1988] AC 618 at 641; Arnull 2010, 70.

Leijon and Glavina 2020; Bobek 2015, 13; Geursen 2020; Tatham 2012.

Mayoral et al 2014, 1136-37.

Liz Barratt as quoted by Sigafoos 2012, 495.

40 Mayoral et al 2014. Cf interviews with the Dutch lower court judges in the fields of consumer and criminal law, Claassen (PhD forthcoming in 2022).

$41 \quad$ Eg Wallis 2008; Nowak et al 2011.

42 Mayoral et al 2014, 1122.

43 Interview 49.

44 Interview 14; Nowak et al 2011.
} 
judges may stem from the idea that it takes a lot of time and effort (a 'whole tour') to ask questions for the first time. ${ }^{45}$ A judge who had recently asked a question for the first time likewise said: 'You first have to clear the hurdle of overcoming the reluctance to refer.' ${ }^{46}$ Dutch judges mentioned that a reference by a lower court judge is 'unique' and receives reactions such as 'Good that you dared to do it!' ${ }^{47}$ One Irish High Court judge mentioned that his/her 'sole knowledge of the matter under consideration is a decade old memory of college lectures about Article 177!' ${ }^{48}$ Another judge, who had never referred, still referred to Article 234 of the EC Treaty, which was replaced by the current Article 267 TFEU back in 2009. This judge was also unaware of the difference between the highest court's obligation to refer and the discretion of the lower courts. ${ }^{49}$ Another judge continuously referred to 'EC law', instead of 'EU law', during the interview. ${ }^{50}$ Likewise, one judge erroneously suggested that individuals can refer a case to the ECJ after exhausting all domestic remedies. ${ }^{51}$ The situation seems even worse at the level of the Irish district and circuit courts. Irish interviewees mentioned that the ability of these courts to draft an order for reference is limited because they are not used to writing judgments. ${ }^{52}$

The limited knowledge of lower court judges is unsurprising, as most of them deal with cases in which references are potentially necessary only once or twice in their career. ${ }^{53}$ This is even more so the case in areas of law where EU law plays a limited role. The low number of references in criminal law cases, except for EAW cases, can also be attributed to the limited awareness of lower court judges of the relevance of EU law and the possibility to refer. ${ }^{54} \mathrm{By}$ contrast, migration law is highly Europeanized, which means that judges are forced to become experts in EU law.

In recent years, however, a generational change has resulted in judges with more extensive knowledge of EU law and a different mindset with respect to referring. This has happened, for example, in the Dutch Council of State. The number of judges in the Dutch Council of State with a great deal of knowledge of EU law increased considerably after Mortelmans became a judge in $2005 .{ }^{55}$ This has also resulted in a higher number of references. Something

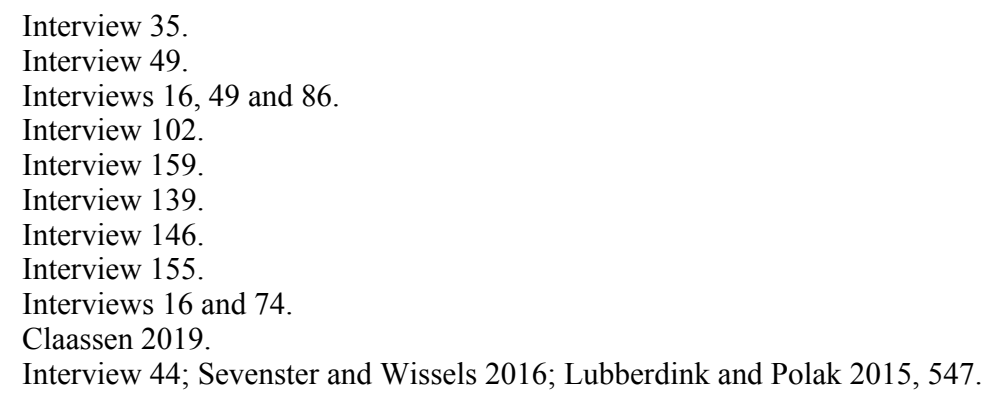


similar happened in Ireland roughly a decade later. The growing number of Irish references can be partly attributed to new and younger judges replacing older judges whose legal education pre-dated Irish accession to the European Community in 1973. ${ }^{56}$ According to some of the Irish judges interviewed, some of those older judges were 'dismayed' when EU law was introduced to Ireland, or saw referencing as 'a big step'. ${ }^{57}$ Older judges were 'steeped in the common law' and tended to frown upon EU law. By contrast, new judges appointed in the past decade are more willing and comfortable with referring - not least because they have studied EU law at university, have practised EU law or have even appeared in Luxembourg as advocates. ${ }^{58} \mathrm{EU}$ law thus posed 'no fear' to them. ${ }^{59}$ In recent years, several (relatively young and/or recently appointed) High Court judges have indeed made their first reference. ${ }^{60}$ These quotes illustrate that a judge's attitude to referring is closely related to his or her amount of knowledge. Generational changes are natural and are certainly not restricted to Ireland and the Netherlands, as Mayoral and Pérez showed in relation to Spain. ${ }^{61}$

At a certain point, too much knowledge of EU law can also be a factor that can discourage references. This seems to be the case for the UK Supreme Court, whose judges are often 'confident' to interpret EU law themselves because they think that they understand the case law, as discussed earlier in Chapter 2, section 3.2. ${ }^{62}$ One UK barrister noted that growing expertise and specialization in EU law have caused both the UK Supreme Court and other courts to refer less, because they (think they) know the answers themselves. ${ }^{63}$ One example is the UK Competition Appeals Tribunal, which deals with EU law on a daily basis, but - ironically - referred for the first time only quite recently, in 2018. ${ }^{64} \mathrm{~A}$ similar logic explains the relatively low number of references from the Irish Supreme Court when three judges with a Luxembourg

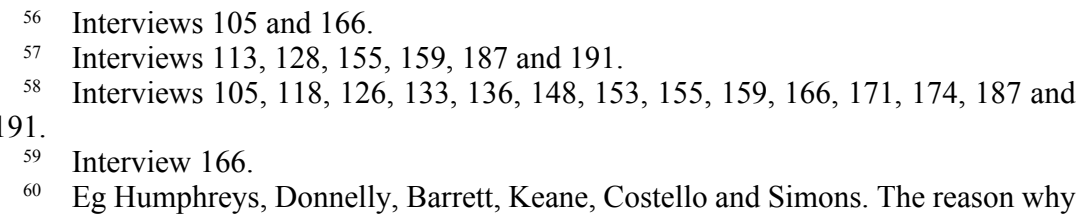
some High Court judges have not been involved in a reference often depends on the cases assigned to those judges and not so much to reluctance or hostility. References are confined to certain areas with a connection to EU law, while there are few references outside those areas, including personal injury, chancery, equity or domestic criminal law. Interviews 102, 105, 148, 152, 155, 188 and 191.

61 Mayoral and Pérez 2018, 728.

62 Interview 243; Arnull 2017, 355-56.

63 Interview 243.

64 Case C-307/18 Generics EU:C:2020:52; Interview 243. 
background subsequently became Supreme Court judges: Fennelly (ECJ 1995-2000; Supreme Court 2000-13), Murray (ECJ 1992-99; Supreme Court 1999-2015) and Macken (ECJ 1999-2004; Supreme Court 2005-12). ${ }^{65}$ Two interviewees noted that the three members knew the answers to questions of EU law and would consider matters to be acte clair quicker ('[W] understand this stuff'). ${ }^{66}$ Likewise, one current Supreme Court judge observed: '[T]here is less confidence when we do not have people from Luxembourg on the court. ${ }^{67}$

The foregoing suggests that the more judges know about EU law, the less likely they are to refer. ${ }^{68}$ There are two caveats, however. First, considerable specialization in particular areas of EU law sometimes leads to a culture in which a reference is more likely. ${ }^{69}$ Dutch customs cases, for instance, are dealt with only by the Noord-Holland District Court and the Amsterdam Court of Appeal; while almost all IP cases go to the District Court of The Hague. ${ }^{70}$ Patent cases in England and Wales are dealt with by a specialized Panel Court on appeal from the UK Intellectual Property Office. ${ }^{71}$ These specialized courts and departments are generally eager to refer. They spot the deficiencies and inadequacies in the ECJ case law and are thus better at 'teasing out the problem'. They are better at controlling their case dockets and can spot commonalities and identify issues that need to go to the ECJ. This has also happened in the UK in fields such as social security, employment and equal treatment, where the Upper Tribunal has traditionally been quite keen to refer. ${ }^{72}$

Second, individual judges and particular courts sometimes contradict the logic of reluctant referrers when they have a lot of EU law knowledge. One good illustration is former Irish High Court (2010-14) and Court of Appeal (2014-18) Judge Hogan, currently AG in the ECJ. As a High Court judge, he

65 The Supreme Court made nine references in the 1990s as opposed to six references in the 2000s. Mallak v Minister for Justice, Equality \& Law Reform [2012] IESC 59 (Fennelly J), para 30; Albatros Feeds $v$ Minister for Agriculture and Foods \& Ors [2006] IESC 52 (Fennelly J).

${ }_{66}$ Interviews 152 and 166.

67 Interview 152.

68 Interview 108.

69 See also the notion of 'hotspots' of references in particular legal areas, Kelemen and Pavone 2018; Stone Sweet and Brunell 1998, 91; Interview 58.

${ }_{70}$ This is not necessarily the case, because the Rotterdam District Court, for example, is the only court that deals with several areas of economic administrative law, but has made relatively few references. In addition, government tax cases are handled by just five of the 14 district courts, but this has not contributed to an increase in references.

71 Arnold 2020, 1105.

72 This barrister (243) nonetheless noted that tribunals have become less eager to refer in those fields and have left this to the higher courts. 
made at least five references - including Schrems, about the invalidity of the US Safe Harbour decision. ${ }^{73}$ In the Court of Appeal, he was also behind most of the references. His extensive knowledge of EU law did not prevent him from referring. On the contrary, according to the judges interviewed, he was as 'an enthusiast' who allegedly saw referencing as 'an intellectual challenge'. ${ }^{74}$ This illustrates that judges and courts with a lot of (specialized) expertise in EU law can have the desire to actively contribute to the development of EU law and/or to challenge the compatibility of national law with EU law.

Another example that is discussed further in Chapter 4 is the references of the Chamber for International Cooperation of the Amsterdam District Court in the context of EAWs. The legal secretary of this Chamber wrote a dissertation on the Dutch law on extradition in relation to EU law. This dissertation hinted at several tensions and possible questions for the ECJ that were subsequently referred by the Chamber. ${ }^{75}$ These examples indicate that personal motives such as prestige or intellectual stimulation can also be a factor, as will be discussed in the following section.

\subsection{Personal Motives}

Closely related to knowledge of EU law and procedure is the attitude and judicial identity of judges in relation to the ECJ and the use of the preliminary reference procedure, as the previous examples of Hogan and the legal secretary of the Dutch Chamber for International Cooperation illustrate. ${ }^{76}$ Another well-known judge who fits the picture of an enthusiastic referrer is Judge Seijo in Spain, who referred the consumer law case Aziz about mortgage foreclosures discussed in Chapter 1 . He is a 'repeat player' and was involved in at least seven references prior to Aziz. He is a Europeanist with an interest in the 'more advanced' system of EU law, and has many contacts with EU law scholars and (former) ECJ judges and AGs. ${ }^{77}$

These examples confirm that the backgrounds and attitudes of judges matter. One Dutch interviewee suggested that judges with an academic or governmental background have a more positive attitude towards the ECJ and are more interested in contributing to the development of EU law. They are also more accustomed to working with a supranational court as the highest authority. By contrast, career judges find it more annoying to refer, since this disturbs their

\footnotetext{
Case C-362/14 Schrems EU:C:2015:650.

Interviews 187 and 191.

Glerum 2013.

Dyevre 2016, 116; Mayoral and Pérez 2018, 725.

Mayoral and Pérez 2018, 729.
} 
autonomy in deciding on disputes, as well as the national judicial process. ${ }^{78}$ Judges with a lifelong career in the judiciary who have made it to the highest court do not suddenly devote themselves completely to the ECJ; instead, they have a more sceptical attitude, asking, 'Is it up to the ECJ to determine this?' 79 Van Gestel and de Poorter reported similar findings based on interviews with judges of supreme administrative courts in ten EU Member States. They found that career judges are more pragmatic and results oriented, and are primarily interested in dispute resolution and reducing their caseload. ${ }^{80}$

Individual judges can shape a particular culture within a court and sometimes even beyond that court, especially in small jurisdictions such as Ireland. ${ }^{81}$ The previously mentioned judge of the Council of State, Mortelmans (2005-16), was 'a fervent advocate' of the reference procedure and internally promoted the need to make (good) references. ${ }^{82}$ The current Irish Chief Justice Clarke was said to be more willing to refer than his predecessors and allegedly does not subscribe to the notion that the ECJ 'should not be telling us what to do' ${ }^{83}$ This attitude is markedly different from that which prevailed a decade earlier, when the Irish Supreme Court was more 'hostile' towards referring, as in the Masterfoods case regarding parallel competition proceedings before the national and EU courts. ${ }^{84}$ Back then, references were not necessarily signs of true engagement with EU law and were primarily made to have Luxembourg sort out complex and delicate issues for the national court. ${ }^{85} \mathrm{~A}$ positive dynamic was also observed in relation to the Irish Court of Appeal when Hogan and Finlay Geoghegan served as judges (2014-17). ${ }^{86}$ When one of them proposed a reference, the other judges would normally defer to them and they would prepare the order for reference ${ }^{87}$ Several of these references, and the prominent references of Hogan as a High Court judge, have also inspired other (High Court) judges to refer. In relation to this, one can think especially

\footnotetext{
Interviews 10 and 44.

Interview 10.

Van Gestel and de Poorter 2019, 112 and 117.

Interviews 108, 113, 148, 166 and 187.

Wissels 2015, 550 .

Interviews 113, 133 and 187.

Case C-344/98 Masterfoods EU:C:2000:689; Interview 113.

85 Eg Case C-221/05, McCauley Chemists EU:C:2006:474; Fahey 2006, 401; One interviewee (188) referred to the equal treatment case of Kenny (C-427/11 EU:C:2013: 122) as an example of a case in which the (criminal law) judge referred an equal treatment case to the ECJ 'to get it off his plate so that he did not have to worry about it'.

86 Metock \& Ors $v$ MJELR [2008] IEHC 77 (Finlay Geoghegan J), para 53.

87 Interviews 113 and 166 . These views are corroborated by the actual references made. There was only one reference in which neither of the two were involved - Case C-640/15 Vilkas EU:C:2017:39.
} 
of Schrems, concerning the invalidity of the US Safe Harbour decision. A similar phenomenon may be observed in relation to the Spanish consumer law references that followed the famous Aziz case on mortgage foreclosures. Aziz promoted 'a new repertoire of judicial tactics' and inspired other judges with less EU law experience to mobilize EU law and refer. ${ }^{88}$

Aside from their attitude towards the ECJ, judges also differ from a more psychological angle in terms of their eagerness to utilize the procedure. Some judges are driven by fear for their reputation; while others derive satisfaction from referring and see this as a way to gain prestige. Some Dutch lower court judges in particular mentioned the risk that the ECJ would dismiss the question too easily or answer it in a way that gave the impression that the referring court did not understand EU law or had overlooked particular ECJ judgments. They expressed the fear that they might miss essential points in their reference and hence preferred not to refer at all. ${ }^{89}$ This suggests that such a fear stems from insufficient knowledge to a large extent. ${ }^{90}$ Judges in Italy, Croatia, Slovenia and Sweden voiced similar concerns. ${ }^{91}$ Pavone quotes from an interview with a judge in Milan: 'It's very risky to refer because your reference could be declared inadmissible. And this becomes known. ${ }^{92}$ However, almost all Irish judges rejected fear as a relevant consideration. ${ }^{93}$ One judge insisted: 'Once it goes, you have to be happy. One should not look over the shoulder all the time.' ${ }^{94}$ One reason why fear seems to play less of a role in Ireland is a heavy reliance on litigants. ${ }^{95}$ One judge held that he/she was not afraid to refer because experienced and 'very good' legal teams from both sides worked out the written reference. ${ }^{96}$ Another judge stated: 'If the reference would make a fool, primarily the parties would make a fool of themselves. ${ }^{97}$ When the ECJ answered the questions by way of order in $M H$, meaning that the answer could be 'clearly deduced from existing case law', this was not seen as a rap on the knuckles of the referring court. Above all, the order was considered a rebuke to the parties, which had failed to refer to the relevant ECJ precedent. ${ }^{98}$

\footnotetext{
88 Mayoral and Pérez 2018, 730 and 732.

89 Interviews $14,49,51,55$ and 74 . Some judges $(16,54,93)$ downplayed this fear. Šadl et al 2020.

90 Pavone 2018.

91 Leijon and Glavina 2020. Cf Pavone 2018.

92 Pavone 2018.

93 Interview 139.

94 Interview 159. Cf Interview 139.

95 Interviews 102 and 144.

96 Interview 121.

97 Interview 102.

98 Interview 166; Case C-173/16 MH EU:C:2016:542; $M H v M H$ [2017] IECA 18

(Finlay Geoghegan J), para 18.
} 
A contrasting personal motivation to refer is that a reference can gain the judge or the court a certain status or prestige at the European level. ${ }^{99}$ Judges were not generally quick to admit this; but one acknowledged that 'it feels very nice' to refer a case that has a significant impact. This judge said that his/her referred case was 'one of the nicest things of the last years', because he/she normally just did 'home, garden and kitchen matters'; a referral is much more demanding. ${ }^{100}$ Enthusiastic judges derive satisfaction from referring and seek to shine by making a reference out of self-assertion. ${ }^{101}$ This also holds true for a few 'activist' judges who consider they have a responsibility to contribute to the development of (EU) law and who use the preliminary reference procedure to leapfrog the judicial hierarchy and seek support from the ECJ. ${ }^{102}$ As will be discussed in the following chapter, this has played a particularly influential role in the field of migration law, where emotions and moral or ethical considerations matter - at least for some judges. Several other Irish and Dutch interviewees mentioned that they liked drafting references because of the intellectual endeavour required. ${ }^{103}$ One Irish judge mentioned that as a young and new judge, he/she was 'prepared to take on extra' in the first year. ${ }^{104}$ Another observed that 'some judges are only too willing to refer. At least they appear so'. ${ }^{105}$ A recent Dutch example that seems to fit into this category is the reference by a single district court judge in Varkens in nood about the compatibility of Article 6:13 of the Dutch General Administrative Law with Article 9(2) of the Aarhus Convention on access to information, public participation in decision-making and access to justice in environmental matters. The referring judge was also employed as a university associate professor. In his decision to refer, the judge noted that he considered the admissibility question, which formed the reason for this reference, from his own motion. He explicitly cast doubt on the case law and approach of the highest administrative court, the Council of State, with respect to Article 6:13. ${ }^{106}$ The ECJ eventually held that the provision indeed breached EU law because it restricted the admissibility of judicial proceedings to NGOs and other interested persons who had participated in the procedure preparatory to the contested decision. ${ }^{107}$ It would appear

\footnotetext{
99 Weiler 1994.

100 Interview 86.

101 Interview 25 and 51.

102 Interviews 29, 55, 83 and 93.

103 Interviews 39 and 86.

104 Interview 187.

105 Interview 136.

106 René Seerden is an associate professor of environmental law at Maastricht

University; Varkens in nood NL:RBLIM:2018:12159, paras 10 and 10.5.

107 Case C-826/18 Varkens in nood EU:C:2021:7.
} 
that UK judges do not see referencing as a way to shine - albeit that it is difficult to conclude this based on the limited number of interviews conducted. ${ }^{108}$ One notable exception is Justice Arnold, who made a considerable number of references in the field of IP law. ${ }^{109}$

Another question is whether career considerations play a role in judges' decisions to refer. Empirical studies in Slovenia and Croatia concluded that negative career prospects could sometimes discourage (lower) courts from referring. ${ }^{10}$ It seems in particular that judges are more wary of upsetting higher court judges through a legally flawed or activist reference in judicially centralized states such as France, where the recruitment, appointment and promotion of judges are centralized. ${ }^{111}$ The analysis of judgments and interviews with judges in the three countries does not suggest that career prospects play a (substantial) role. This can possibly be explained by the strong independent and autonomous status of judges in the three countries and the absence of centralized disciplinary measures. ${ }^{112}$

\section{INSTITUTIONAL}

The previous section pointed to a certain culture in particular courts and the ability of individual judges to shape that culture. Institutional or managerial factors are closely related to the functioning of departments of and within courts. ${ }^{113}$ One first institutional element is coordination. Enhanced coordination of EU law partly explains why the Dutch Council of State has paid more attention to EU law and referred more often in the past decade. EU law questions are now coordinated better because of the creation of a committee on EU law and a documentation service that keeps close track of EU law developments. ${ }^{114}$ This committee consists of members of different chambers of the court. It discusses EU law developments and cases that are likely to be referred. ${ }^{115}$ It also tries to bundle cases to be referred jointly, as happened in Willems regarding biometric data and passports. ${ }^{116}$ In Spain, an EU law

\footnotetext{
108 Interview 231.

109 Eg Société Des Produits Nestlé SA v Cadbury UK Ltd [2016] EWHC 50 (Ch), Arnold 2020.

110 Leijon and Glavina 2020.

111 Pavone and Kelemen 2019; van Gestel and de Poorter 2019, 123.

112 Cf Germany, Pavone and Kelemen 2019; Alter 1998, 238.

113 Cf meso-level determinants, Dyevre 2016, 116; Bobek 2013a, 67.

114 Interviews 18, 44, 81 and 89.

115 The Dutch Administrative High Court also holds such meetings, Interviews 24, 66 and 89.

116 Van Gestel and de Poorter 2019, 5.
} 
network with judges specialized in EU law has also had a positive impact in terms of the coordination of references. ${ }^{117}$

A second institutional aspect affecting the decision to refer is the case management system within courts. This has played a strong role at the level of the Dutch lower courts. In the Netherlands, references are discouraged by a financial system which rewards judges based on the number of cases they decide. There is increased pressure on the capacity of courts and there is a tendency among lower court judges to favour the resolution of disputes without referring. ${ }^{18}$ Dutch district courts are 'decision-making machines'; there is no time to 'go into the study and answer legal questions'. ${ }^{119}$ Recent work on the Slovenian and Croatian (lower) courts also pointed to such time and numerical targets; while research on the Italian lower courts highlighted pressures due to their high caseload. ${ }^{120}$ Pavone refers to the 'economy of everyday judging', with judges who simply 'don't have the time', and points to 'institutional path-dependencies' that have prevented EU law from becoming embedded within general day-to-day routines in the lower courts. ${ }^{121}$ The pressure to make a decision on time, in combination with holiday periods, can mean that an initial intention to refer is not realized. One judge pointed to such logistical issues, which eventually prevented a referral. He/she noted that a reference 'messes up your normal workflow' and leads to 'backlogs' and 'extra work'. ${ }^{122}$ There are considerable differences among the Member States. However, Irish judges were adamant in rejecting the notion of production targets. One judge stated: 'Gosh no! That can never be a factor.' ${ }^{23}$ Irish judges do not factor in delays in judicial decision making, as was discussed in Chapter 2, section 3.5. Judges want to do things correctly and the merits are all that matter. ${ }^{124}$ One judge, however, noted that it is not 'us', the judges, who are under pressure, but rather the system, for which the state is responsible. He/she mentioned the judge's 'selfish point of view' that it is not his or her fault that referring takes 15 months extra where necessary. ${ }^{125}$ The fact that Ireland has the lowest number of judges per capita in the EU, as several interviewees highlighted, does not affect judges in their actual decision making or willingness to refer. ${ }^{126}$

\footnotetext{
117 Ibid, 122.

118 Interviews 14 and 20.

119 Interviews 58, 74 and 93.

120 Glavina 2020b; Leijon and Glavina 2020; Pavone 2018.

121 Pavone 2018.

122 Interview 93. Almost all judges who have experience with drafting a reference acknowledged that it requires a lot of work, Interviews 8, 16, 39, 55 and 93.

123 Interviews 139, 136, 144, 146 and 181.

124 Interviews 139 and 187.

125 Interview 144.

126 Interviews 108, 113, 146, 159 and 187; Fahey 2004, 12.
} 
This confirms that the independence of individual judges is guarded very carefully. ${ }^{127}$

A third related institutional aspect is the available capacity within a court. ${ }^{128}$ A Dutch district court judge noted that district courts decide 90 per cent of all court cases with a relatively low number of judges: '[J]udges who might harbour the desire to refer, have the manpower dictating against that. ${ }^{129}$ This view was shared by other judges, who noted that the level of back-up and support staff is limited in the lower courts. ${ }^{130}$ The relevance of capacity is illustrated by the four references made by the Den Bosch Court of Appeal in 2012 within a six-week period; whereas the same court made no references in the following four years. This was attributed to the availability of extra time and capacity during that particular period. Recent empirical studies have also suggested that a heavy workload and limited resources militate against references being made, especially by the lower courts. ${ }^{131}$ The higher resource/ workload ratio of the highest courts thus positively affects their ability to refer. ${ }^{132}$ The highest courts are better equipped to refer in terms of the level of support staff, the greater number of judges involved and the preceding opinion of the AG at the level of the Supreme Court. ${ }^{133}$ This is also the perception of the lower courts, which further encourages them to avoid making references to the highest courts (section 2.1). In their view, the highest courts are better able to provide the optimal questions and information to the ECJ. This was one reason why the Zeeland-West-Brabant District Court used the national preliminary ruling procedure and referred a question about the interpretation of EU law to the Supreme Court instead of referring directly to the ECJ. ${ }^{134}$

In short, institutional and organizational aspects impact the willingness and ability of judges to refer. These include the coordination of EU law; case management and production targets; and capacity and resource/workload ratio.

\section{THE ROLE OF THE PARTIES}

Another factor that influences courts' willingness to refer is the role of the parties and their requests to refer. The parties have a particularly strong influence on the decisions of UK and Irish courts (not) to refer, primarily due to

\footnotetext{
127 Interviews 136, 139, 144 and 177.

128 Interview 22.

129 Interview 146.

130 Interviews 135, 155 and 191.

131 Leijon and Glavina 2020; Pavone 2018; Mayoral and Pérez 2018, 731.

132 Dyevre et al 2020.

133 Interviews 35, 51, 58, 74 and 93.

134 NL:RBZWB:2017:2454, para 4.18.
} 
the adversarial nature of the legal system. The courts in these two common law countries decide on the basis of the submissions of the parties and rely to a great extent on those submissions. ${ }^{135}$ One Irish judge mentioned that judges do not always conduct their own research, especially if their instinct is that the parties are right and if the parties have good barristers. ${ }^{136}$ There is thus great trust in the (lawyers of the) parties. UK judges attributed this to the high standard of the bar and the idea that informed lawyers will always bring up issues of EU law. ${ }^{137}$ This reliance on the parties would be unthinkable in the Netherlands. The important role of the parties is obscured by the fact that judgments in all three countries rarely explicitly refer to requests in the decision to refer or the orders for reference. For example, only one of the 15 decisions to refer made by the UK Supreme Court since 2013 mentioned a draft reference proposed by the parties - ClientEarth. ${ }^{138}$ The interviews and the analysis of court proceedings confirm that there have been more requests in other cases. ${ }^{139}$

The Irish and UK courts, as well as the Dutch lower courts, would rarely refer without a request. ${ }^{140}$ Pavone reached a similar conclusion in relation to the Italian lower courts. ${ }^{141}$ Only in a small number of cases was a reference made by the Irish and UK lower courts without a request from the parties. ${ }^{142}$ One Irish judge, for example, held: ' $[\mathrm{I}] \mathrm{t}$ is a rare event that I take it upon myself.' ${ }^{143}$ Another stated: '[I]f the parties do not articulate the need for a reference with some clarity, than I am not in a position to refer ... they cannot have

135 Interviews 113, 148, 155, 159 and 276; Maher 2018, 180; Fahey 2007, 19. Cf Danish judges; Rytter and Wind 2011, 493.

136 Interview 174.

137 Interview 231 and 276.

138 Two of the 15 Supreme Court decisions to refer/orders for reference were not retrieved, ClientEarth, $R$ (on the application of) $v$ The Secretary of State for the Environment, Food and Rural Affairs [2013] UKSC 25, para 40.

139 Interview 264. One example is C-430/15 Tolley EU:C:2017:74. This can be derived from the decision of the Upper Tribunal, which refers to a request of de la Mare, who also acted as a barrister before the Supreme Court, SSWP v LT (DLA) [2012] UKUT 282 (AAC), para 52. There was also a request in SSHD v Franco Vomero [2016] UKSC 49; Interview 276.

${ }_{140}$ A reference can also be the result of the judge 'probing the parties' without a specific request from either side. Interview 136, 153, 166, 191, 231 and 264; Heyvaert et al, 2014. One example given is Boggis, $R$ (on the application) v Natural England [2009] EWCA Civ 1061.

141 Pavone 2018.

142 Eg Schrems v Data Protection Comr [2014] IEHC 310 (Hogan J; C-362/14 Schrems EU:C:2015:650); Wilson \& Anor v McNamara \& Ors [2020] EWHC 98 (Ch), para 118; AMS v SSWP [2017] UKUT 48 (AAC) (Ward J), para 1; TG $v$ SSWP [2015] UKUT 50 (AAC), para 68; Euro Trade and Finance Ltd $v$ HMRC [2016] UKFTT 279 (TC), para 230.

143 Interview 159. Cf Interviews 133, 148, 153, 155, 162174 and 191. 
me dream something up.' ${ }^{144}$ This also holds true for the Irish Supreme Court, even though it seems to be slightly quicker to refer on its own initiative than other Irish courts. ${ }^{145}$ Courts are also generally unwilling to refer unless both parties are in favour. ${ }^{146}$ One former Supreme Court judge stated: 'We do not want to give the parties unnecessary trouble. ${ }^{147}$ And where the government is opposed, 'as a rule of thumb', the chance of a reference is very slim. ${ }^{148}$ The UK courts in particular have been open about this in their judgments. In Bulmer, Lord Denning determined that courts 'should hesitate before making a reference against the wishes of one of the parties, seeing the expense and delay which it involves'. ${ }^{149}$ This quote, and variants thereof, have been repeated by other courts. ${ }^{150}$

Where both parties want a reference, this does make a difference and the court is more likely to refer - even though courts emphasize that they are in no way obliged to do so. ${ }^{151}$ Two UK barristers likewise observed that where the government is in favour of a reference in public or tax law cases, this will almost always happen. ${ }^{152}$ Where both parties want a reference, judges 'are more inclined to think that it is an arguable point of law'. ${ }^{153}$ One example is the reference in Brockenhurst College, where the parties jointly submitted a letter

144 Interview 144

145 Interviews 105, 113, 152 and 153.

146 Interviews 211 and 276; Shirley \& Anor, $R$ (on the application of) $v$ The Secretary of State for Housing, Communities and Local Government [2019] EWCA Civ 22, para 63; Brownlie v Four Seasons Holdings Inc [2015] EWCA Civ 665.

147 Interview 264. The current UK Supreme Court nonetheless noted: 'Parties will often not want a matter to be referred, given the extra delay and expense that will cause. That, however, does not impact on the court's obligation to refer.' Written response 15 April 2020. One former Supreme Court judge (208) likewise noted that the court does not depend on the parties and that it is obliged to apply the test in any case.

148 Nonetheless, it does not need to be difficult to convince the government to refer, because a reference can also be used tactically as a strategy to 'delay a loss' and to create 'breathing space', Interview 243.

149 HP Bulmer Ltd \& Anor v J Bollinger SA \& Ors [1974] EWCA Civ 14.

150 Eg Arnold would have made a reference 'had it not been for the applicant's opposition'. Société Des Produits Nestlé SA v Cadbury UK Ltd [2014] EWHC 16 (Ch), para 48; Xv Kuoni Travel Ltd [2018] EWCA Civ 938 (later referred in Case C-578/19 Kuoni Travel).

151 Interviews 231 and 264. Eg Actavis Group PTC EHF \& Anor v Boehringer Ingelheim Pharma GmbH and Co, KG [2013] EWHC 2927 (Pat), paras 7 and 18; GlaxoSmithKline Biologicals SA v Comptroller-General of Patents, Designs and Trade Marks [2013] EWHC 619 (Pat), para 82.

152 Interviews 211 and 243.

153 Interview 264. 
in which they argued that a reference was necessary. A draft of the questions was attached to the letter. ${ }^{154}$

At times, intervening parties have also had an impact on the decision to refer. The involvement of specialist legal charity the Advice on Individual Rights in Europe (AIRE) Centre is said to have an impact, because the organization is regarded highly by the UK courts. ${ }^{155}$ A UK barrister observed that the AIRE Centre's interventions highlighting points of general importance and requests for a reference are frequently heeded, even where the government or the parties are opposed. ${ }^{156}$ One recent example was $S M$, about a child's guardianship under the Algerian kafala system. ${ }^{157}$ As a matter of fact, the AIRE Centre has been involved in eight references in the field of asylum, migration and social policy over the past decade.

Requests of the parties have had less of an impact on the Dutch highest courts. Most decisions to refer were actually made by the courts on their own initiative. ${ }^{158}$ Pavone also found something similar in relation to the Italian highest courts. ${ }^{159}$ Usually, a request is merely one of many factors that play a role. ${ }^{160}$ Supreme Court judges emphasized that they take requests into consideration, but they themselves make autonomous decisions. ${ }^{161}$ Interviewees indicated that a request makes little difference in the case of a Supreme Court 'that takes its task seriously', because the question always comes up, regardless of whether the parties have made a request. ${ }^{162}$ In fact, even if nothing has been argued by the parties, the court will look 'with a slanted eye' to determine whether there is a question about EU law and whether it is clair or éclairé. ${ }^{163}$ It is not the case that the Supreme Court suddenly discovers through the request of a party that different interpretations of EU law are possible. ${ }^{164}$ More often than not, the Supreme Court itself flags the disputed point of EU law. For instance, a preliminary reference was made in Gemeente Woerden about VAT reduction even though the legal question referred was not raised in the (written) pleas of the parties. ${ }^{165}$ In De Lange, the Dutch Tax Chamber

154 HMRC v Brockenhurst College [2015] EWCA Civ 1196, para 9.

155 www.airecentre.org/the-aire-centre.

156 Interview 211; Cf Sigafoos 2012.

157 Case C-129/18 SM EU:C:2019:248.

158 Interviews 10, 12, 19 and 43.

159 Pavone 2018.

160 Interviews 41 and 59.

161 Interviews 33, 41 and 78.

162 Interviews 30, 33, 41, 48 and 82.

163 Interviews 15 and 33 .

164 Interview 30.

165 Gemeente Woerden NL:HR:2015:1355 (Case C-267/15 Gemeente Woerden EU: C:2016:466); Interview 33. 
referred questions about the conformity of a tax deduction scheme of study costs for people below 30 years with the prohibition against age discrimination in the Equal Treatment Directive 2000/78. ${ }^{166}$ The parties had not raised this point, except for a rather general reference to the prohibition of discrimination in international treaties. Supreme Court judges noted that a request is seldom made by the parties, because they generally want legal certainty and a quick decision. ${ }^{167}$ Dutch lower court judges attach more importance to the parties' requests. ${ }^{168}$ They argued, in line with the UK and Irish courts, that a reference without a request from one of the parties is rare. ${ }^{169}$

In all three countries, the frequency of requests has increased in recent years. Interviewees observed that there has also been a growing number of requests by (one of) the parties - especially on migration law issues, such as in free movement and asylum cases. ${ }^{170}$ Both the Irish and UK leave to appeal forms mention the preliminary reference procedure and ask whether the applicant wishes to make a reference. With the exception of the UK Supreme Court and the Civil Chamber of the Dutch Supreme Court, judges were generally critical of the quality of requests, noting that most are badly substantiated or irrelevant. ${ }^{171}$ Most requests are made as an alternative submission, whereby the parties are not as such interested in a reference. ${ }^{172}$ The parties frequently request a reference if the court does not accept their substantive arguments. ${ }^{173}$ Some judges see this as a 'sign of weakness' and state that the parties could perhaps better defend their point beyond doubt, without a need for referral. ${ }^{174}$

Irish and UK judges also involve the parties more closely in drafting the order for reference. They 'heavily rely' on the parties to get a potential question for a preliminary reference right. ${ }^{175}$ The parties are almost always asked

166 De Lange NL:HR:2015:3022 (Case C-548/15 De Lange EU:C:2016:850); Interview 30.

167 Interviews 23, 27, 41, 48, 59, 79 and 87.

168 Interviews 35 and 93.

169 Interviews 22, 83 and 86.

170 Interviews 30, 33, 34, 82, 105, 108, 113, 144, 148, 152 and 161.

171 Interviews $8,10,12,24,25,29,25,35,72,74,93,102,105,108,136,139,144$, $161,162,181$ and 187.

172 Interview 264; Simonis, $R$ (on the application of) v Arts Council England (Rev 2) [2020] EWCA Civ 374, para 7.

173 Interviews 15, 30, 33, 78, 82, 211 and 231. Eg Leeds City Council v HMRC [2015] EWCA Civ 1293, para 51; Air Canada \& Ors v Emerald Supplies Ltd \& Ors [2015] EWCA Civ 1024; Chester, $R$ (on the application of) $v$ The Secretary of State for Justice (Rev 1) [2013] UKSC 63, para 20.

174 Interviews $15,30,33,78$ and 82.

175 Interviews 102 and 187; Fahey 2007, 20. 
to propose draft questions and a draft reference. ${ }^{176}$ A good illustration is the order drafted by the parties in Philip Morris, which was referred subject to one small amendment by the judge. ${ }^{177}$ Some UK judges are more in control. High Court Judge Arnold (now Lord Justice), who has immense experience with references, has formulated drafts and has consulted counsel regarding the precise wording of their questions. ${ }^{178}$ One UK barrister clearly rejected the notion that courts are lazy in allowing the parties to draft the order for reference to a significant extent. He/she held that when the order is the result of an argument between the parties, this enhances the quality of the order for reference. ${ }^{179} \mathrm{~A} \mathrm{UK}$ judge also reasoned that the involvement of the parties in the formulation of the questions is considered helpful and necessary, especially given that the parties will eventually have to debate them in Luxembourg. ${ }^{180}$ Lord Reed pointed to the House of Lords' reference in Aimia Coalition, which was drafted by one of the parties without a hearing and with the limited involvement of the other party and the House of Lords. ${ }^{181}$ This resulted in a 'disastrous' and 'shambolic' outcome, as will be discussed later. According to Reed, the practice of the Supreme Court since his accession to the bench in 2012 has been to refer only after hearing the parties and with substantial input from the parties in the drafting of the order for reference. ${ }^{182}$ Some of the Dutch highest courts have also started to present a draft of the questions to the parties before referral, but this is certainly not a consistent practice. ${ }^{183}$

In conclusion, the parties' requests to refer are an essential factor in courts' decision to refer, especially in adversarial systems, where the courts are unlikely to refer on their own initiative. This suggests that increased knowledge of EU law among lawyers has an impact on EU law-related litigation, resulting in more requests to refer. Previous research underscores this. The two lawyers of Mr Francovich, for instance, received their EU law education from the former référendaire of the ECJ, Judge Trabucchi. ${ }^{184}$ The high level

176 Eg International Stem Cell Corporation v Comptroller General of Patents [2013] EWHC 807 (Ch), para 59; Interview 211. One notable exception is Case C-621/18 Wightman EU:C:2018:999.

177 Philip Morris Brands SARL \& Ors $v$ The Secretary of State for Health [2014] EWHC 3669 (Admin), para 11. Cf MS v PS [2016] EWHC 88 (Fam), para 43.

${ }_{178}$ Eg Société Des Produits Nestlé SA v Cadbury UK Ltd [2014] EWHC 16 (Ch), para 77.

179 Interview 243.

180 Interview 208.

181 Reed 2014, 12.

182 Ibid, 13.

183 Eg Synthon v Astellas Pharma Inc NL:HR:2016:2643 (Case C-644/16 Synthon EU:C:2018:61); Interview 27.

184 Bartolini and Guerrieri as discussed by Pollack 2017, 586. 
of litigation in relation to EU law in Genoa was also attributed to the work of one law firm. ${ }^{185}$ Differing rates of litigation and mobilization thus explain the variations among the Member States, as well as the differences across legal areas and over time within each Member State. ${ }^{186}$ Kelemen and Pavone found that domestic litigiousness explains the disparity in Italian references since 1997. ${ }^{187}$ Increased litigation and knowledge of EU law among lawyers have helped to drive the increase in Irish references, and it is thus not surprising that Dublin has become a true 'hub' for EU law, with specialized Euro-lawyers and major law firms. ${ }^{188}$ In some areas, such as criminal law, the parties have yet to discover the potential of EU law. ${ }^{189}$

\section{CONCLUSION}

This chapter has demonstrated that several individual and organizational factors affect judges' decisions (not) to refer. Three personal and psychological considerations in particular play a role: the judge's perspective on the court's role as a court of first or second instance vis-à-vis the country's highest court(s); knowledge of EU law; and the identity, background and attitude of judges. There are also three important institutional factors: coordination of EU law; the case management system; and available capacity. The parties and their lawyers also influence the decision (not) to refer, at least for lower courts and courts in adversarial systems such as the UK and Ireland.

185 Kelemen and Pavone 2016, 1127.

186 The level of mobilization depends on the amount of court fees, the availability of legal aid, requirements as to representation by a lawyer, the direct effect of EU law provisions and national standing rules; see Kelemen and Pavone 2016, 2017; Conant et al 2018; Cichowski 2007, 245-51; Dougan 2020, 52; Passalacqua 2021.

187 Kelemen and Pavone 2018.

188 Krommendijk 2020. Cf Hoevenaars 2020.

189 Claassen 2022. 